\title{
A multi-century eastern white pine tree-ring chronology developed from salvaged river logs and its utility for dating heritage structures in Canada's National Capital Region
}

Post-print/Accepted manuscript

Melissa Dick

Trevor J. Porter

Michael F.J. Pisaric

Ève Wertheimer

Peter deMontigny

Joelle T. Perreault

Kerry-Lynn Robillard

Dick, M., Porter, T.J., Pisaric, M.F.J., Wertheimer, È., deMontigny, P., Perreault, J.T., Robillard, K.-L. (2014). A multi-century eastern white pine tree-ring chronology developed from salvaged river logs and its utility for dating heritage structures in Canada's National Capital Region. Dendrochronologia, 32(2), 120-126. doi: 10.1016/i.dendro.2014.02.001

\section{HOW TO CITE TSPACE ITEMS}

Always cite the published version, so the author(s) will receive recognition through services that track citation counts, e.g. Scopus. If you need to cite the page number of the TSpace version (original manuscript or accepted manuscript) because you cannot access the published version, then cite the TSpace version in addition to the published version using the permanent URI (handle) found on the record page. 
1 A multi-century eastern white pine tree-ring chronology developed from salvaged river logs and its

2 utility for dating heritage structures in Canada's National Capital Region

4 Melissa Dick $^{1}$, Trevor J. Porter ${ }^{1,2}$, Michael F.J. Pisaric ${ }^{*}, 1,3$, Ève Wertheimer ${ }^{4}$, Peter deMontigny ${ }^{1}$, $5 \quad$ Joelle T. Perreault ${ }^{1}$, and Kerry-Lynn Robillard ${ }^{1}$

$7 \quad{ }^{1}$ Department of Geography and Environmental Studies, Carleton University, Ottawa, Canada

$8{ }^{2}$ Department of Earth and Atmospheric Sciences, University of Alberta, Edmonton, Canada

$9 \quad{ }^{3}$ Department of Geography, Brock University, St. Catharines, Canada

$10{ }^{4}$ Heritage Program, Capital Planning Branch, National Capital Commission, Ottawa, Canada

12 *Author of correspondence. E-mail: mpisaric@brocku.ca; Tel.: +1-905-688-5550; Fax: +1-905-

$13 \quad 688-6369$

14 Key words: dendroarchaeology; tree-ring width; eastern white pine; heritage log structures;

15 vernacular buildings; Ottawa; Gatineau

\section{ABSTRACT}

The early settlement history of Canada’s National Capital Region, including Ottawa

19 (Ontario) and Gatineau (Québec), was shaped in large part by the towering eastern white pine

20 (Pinus strobus) forests that once covered the Ottawa Valley and fuelled a lucrative lumber export

21 industry spanning the $19^{\text {th }}$ and much of the $20^{\text {th }}$ century. Some of the first dwellings and farmsteads

22 of this era are still standing and serve as reminders of this history. A crucial piece of information in

23 the assessment of a structure's heritage value is its date of construction. Unfortunately, this 
1 information is not always known and is approximated based on construction styles and other

2 sources of information. In this study, dendroarchaeology methods are applied to constrain the

3 construction dates of six historic structures in the National Capital Region of $19^{\text {th }}$ century vintage.

4 A multi-century (AD 1670-2009) eastern white pine ring-width chronology was developed for

5 dating the study structures using cross sections from sunken logs recovered from the Ottawa River

6 and cores from live trees from the Petawawa Research Forest. The tree-ring inferred construction

7 dates for the six structures ranged from 1830 to 1878 . For most structures, historical records about

8 the property or first inhabitants were available to corroborate the results. The ring-width

9 chronologies of the individual structures were well correlated with the regional chronology $\left(\mathrm{r}_{\mathrm{avg}}=\right.$

$100.63, \mathrm{p} \leq 0.01$ ), and this regional coherence clearly demonstrates the value of tree-rings for

11 heritage structure assessments and reconstructing the settlement history of this region.

\section{INTRODUCTION}

14 The Ottawa-Gatineau region, also known as Canada's National Capital Region, was an

15 important centre in the Canadian timber trade during the $19^{\text {th }}$ and $20^{\text {th }}$ centuries. The Ottawa River

16 was an important waterway to transport lumber used for the construction of buildings, ships and

17 furniture in eastern North America and foreign markets. Towering, old-growth eastern white pine

18 (Pinus strobus L.) was abundant in this region and valued in construction for its straight and

19 relatively strong trunks. Given the high demand and quality of the wood, the timber trade of the

$2019^{\text {th }}$ and $20^{\text {th }}$ centuries removed most of the old-growth white pine forests in eastern Ontario.

21 Today, some of the oldest re-growth white pine stands are found in the Petawawa Research Forest

22 (Fig. 1), and isolated trees upwards of 200-400 years are known to exist in parts of Algonquin

23 Park, Ontario (Guyette and Dey, 1995; Guyette and Cole, 1999). 
The combination of tree-ring series from living and dead trees provides an opportunity to

2 develop long tree-ring chronologies for dendrochronology research. Pertinent to this study is the

3 use of tree-rings for dating structures built from local timbers. Dendroarchaeology methods have

4 been applied to numerous buildings and antiquities around the world (Getty, 1935; Grissino-Mayer

5 et al., 2004; Wang et al., 2008; Pearson et al., 2012, Becker et al., 1985) and elsewhere in Canada

6 (Smith, 2000; Smith et al., 2005; Selig et al., 2007; Robichaud and Laroque, 2008; Pickard et al.,

7 2011), but remain underutilized in eastern Ontario despite the occurrence of archaeological

8 artifacts such as dugout canoes (Johnston, 1962; Rogers, 1965; Mitchell et al., 1968) and numerous

9 heritage buildings (Aldred, 1989) that lack precise information about dates of construction.

In the National Capital Region, part of the mandate of the National Capital Commission

11 (NCC) is to preserve the 'built heritage' of the region, and there are numerous log barns and

12 dwellings of interest in the NCC's jurisdiction with construction dates that are only loosely known

13 from historical records (e.g., land registry documents), mostly of early to late $19^{\text {th }}$ century vintage.

14 Here, dendroarchaeology methods are applied to provide independent age constraints on five of

15 these structures and one privately-owned dwelling in the National Capital Region (Fig. 1). All of

16 the log structures were built using eastern white pine timbers that predate existing forests of the

17 region and, therefore, developing a useful reference chronology was a challenge. Multi-century

18 eastern white pine chronologies have been compiled in Algonquin Park using logs buried in the

19 littoral zone of lakes (Guyette and Cole, 1999). We apply a similar strategy to develop our

20 reference chronology (AD 1670-2009) using white pine logs salvaged from the bed of the Ottawa

21 River. Most of these logs were floated down river by lumberjacks, but some of these sunk before

22 reaching the lumber mills in Ottawa. The most recent portion of our reference chronology is

23 developed using living trees from the Petawawa Research Forest. The reference chronology 
1 provides unambiguous cross-dating results when compared with tree-ring growth patterns from the

2 heritage structures of interest, and these results are well supported by the historical records. This

3 study demonstrates the viability of dendroarchaeological methods to improve knowledge of the

4 early settlement history of the National Capital Region.

5

\section{METHODS}

7 Development of the regional pine chronology

9 Valley, located $\sim 200 \mathrm{~km}$ northwest from Ottawa (Fig. 1). The modern forest is a mixture of eastern

The Petawawa Research Forest is a 10,000 ha mixed mature forest in the upper Ottawa white pine, red pine (Pinus resinosa Ait.), jack pine (Pinus banksiana Lamb.), trembling aspen (Populus tremuloides Michx.), white birch (Betula papyrifera Marsh.) and red oak

(Quercus rubra L.). This area was at the centre of the timber trade in the $19^{\text {th }}$ and $20^{\text {th }}$ centuries, and selective logging during the late $19^{\text {th }}$ century removed most of the largest and oldest white pine (Canadian Forest Service, 1998). This area has been protected from logging for most of the $20^{\text {th }}$ century and provides access to some of the oldest re-growth white pines in the province, needed to anchor the Ottawa River tree-ring chronology. Tree cores were collected from 14 eastern white pine trees at the Petawawa Research Forest in 2010 using Hagloff increment borers. Sample cores were stored in straws, air dried, mounted, and sanded with progressively finer grits of sand paper (Speer, 2010). The living white pine samples were visually cross dated and measured $( \pm 0.001 \mathrm{~mm})$ using a Velmex tree-ring measuring system. The computer program COFECHA was used to verify the cross-dating results (Holmes, 1983). A mean chronology was developed from these samples and used to anchor the Ottawa River log samples in time. 
In some areas, the Ottawa River is an ideal environment to preserve sunken logs because

2 the bottom waters lack oxygen and light which would otherwise cause the logs to degrade. Cross

3 sections of 35 white pine logs recovered from the bed of the Ottawa River were provided by a

4 local wood products company (Logs End) in Quyon, Quebec. The preservation of the logs was

5 exceptional, and in many cases the original stamp of the lumber companies that harvested the logs

6 was still visible (Fig. 2). These samples were sanded to a smooth finish and measured using a

$7 \quad$ Velmex tree-ring measuring system. Since felling dates of the river samples were unknown and

could span more than a century, cross-dating was completed initially by computer-assisted

9 methods and later verified by visually cross-dating based on common marker rings. An undated

master floating chronology was developed iteratively by cross-dating the river samples against

each other. All but one of the Ottawa River samples was successfully cross-dated and added to the master floating chronology, spanning 317 years.

The floating chronology was anchored in time by cross-dating it against the Petawawa

14 Research Forest living chronology. Again, COFECHA was used to identify the most statistically-

significant calendar age assignment. In addition to the correlation results, a visual inspection of common growth patterns and a sign-test were used to verify the results. The sign-test statistic is expressed here as the percentage of agreements in sign between the chronologies with respect to interannual variability. The Petawawa and Ottawa River series were then combined into a master white pine chronology that served as the reference chronology for dating the heritage structures.

Study sites in the National Capital Region 
1 privately-owned structure in this study is the Cherry Cottage. Historical records of varying levels

2 of detail are available for all of these properties, mainly from land registry documents, but in all

3 cases there are no explicit statements on construction dates. Logs from these structures were

4 sampled using a custom dry-wood borer, patterned after other designs in the literature (Grissino-

5 Mayer et al., 2010). Core samples were taken from logs that constitute original beams and

6 structural timbers. All of the sampled timbers, whether full log beams or partial logs, are hereafter

7 referred to as 'logs'.

Deteriorated or squared timbers can only provide a terminus post quem. However, when

9 the waney edge or natural curvature of the log is intact, the felling date can be determined from the

10 terminal ring. Nearly all of the core samples reported here were from waney edges. In most cases,

11 one core was collected from each log. If multiple cores were taken, they were from opposite sides

12 of the log and several metres apart, if possible. Cores were prepared and measured using the same

13 methods described for the Petawawa and Ottawa River samples. Duplicate ring-width series (i.e.,

14 from the same log) were averaged together. Ring-width series from a given heritage structure were

15 first cross-dated internally by visual inspection and COFECHA to establish a floating chronology

16 for the site. The mean floating chronology was then cross-dated against the master white pine

17 chronology to determine its absolute chronology and the felling dates of the individual series.

18 Addition of all heritage structure ring-width series to the master white pine chronology improved

19 the regional sample depth and significance of cross-dating results. The quantitative cross-dating

20 results for each site below are based on comparisons with the augmented master white pine

21 chronology (i.e., including heritage samples), but minus the influence of samples from the site

22 being evaluated. 
Lastly, for waney edge samples, the presence of late-wood (Figure 2) in the terminal ring

2 was noted to provide further information on the season the logs were felled. If late-wood was

3 present, the terminal ring could represent a complete ring and, therefore, the log may have been

4 felled during the late growing season or winter-spring following the growing season, but before the 5 next year's growth had begun.

\section{RESULTS AND DISCUSSION}

\section{Ottawa River-Petawawa chronology}

9 In total, 34 Ottawa River logs and 14 living trees from the Petawawa Research Forest were 10 compiled to form the Ottawa River-Petawawa reference chronology. The river logs are strongly 11 correlated internally with a mean inter-series correlation of $0.48(\mathrm{p} \leq 0.01)$. By contrast, the mean 12 inter-series correlation for the living trees is $0.52(\mathrm{p} \leq 0.01)$, slightly higher than that of the Ottawa 13 River logs. This result is understandable given that the Petawawa trees are from a single site with similar microclimate conditions, whereas the Ottawa River logs are likely from multiple unknown sites upstream from Ottawa, which would be expected to have greater ring-width variability.

16 The Ottawa River floating chronology was most strongly and significantly correlated with

17 the Petawawa chronology when the floating chronology's start year is set to AD 1670 and its end 18 year is set to AD 1986. The distribution of Ottawa River log felling dates (Fig. 3a) spans the mid$1919^{\text {th }}$ to late $20^{\text {th }}$ century, which coincides well with logging activities on the Ottawa River. The 20 correlation between the two chronologies during their period of overlap (AD 1908-1986) is 0.45 (t $21=5.0, \mathrm{p} \leq 0.01)$, with $67 \%$ agreement for the sign-test $(\mathrm{p} \leq 0.01)($ Fig. $3 b)$. The moderate

22 correlation implies a regionally coherent climate signal shared by the Ottawa River and Petawawa 23 trees, which probably grew at sites separated by many tens of kilometers. However, this level of 
1 agreement is expected of eastern white pine, which typically correlates well across regions and is

2 recognised as a species of major importance to dendrochronological research for this reason

3 (Grissino-Mayer, 1993).

4

Ottawa-Gatineau heritage samples

In total, 34 logs were sampled from the six heritage structures (Fig. 4). These samples span

7 AD 1673-1878 with felling dates ranging from AD 1830-1878 (Fig. 3c), in close agreement with

8 the expected vintage of the structures (discussed more fully in the following sections). Regionally,

9 the heritage samples are well correlated with each other, with a mean inter-series correlation of

$10 \quad 0.51(\mathrm{p} \leq 0.01)$. The Ottawa River-Petawawa and Ottawa-Gatineau chronologies are each defined

11 by two or more series during the period AD 1756-1877, with an inter-series correlation of $0.42(\mathrm{t}=$

$125.0, \mathrm{p} \leq 0.01)$ and $68 \%$ agreement for the sign-test $(\mathrm{p} \leq 0.01)$ (Fig. 3d). A number of pointer years

13 were common and useful for cross-dating. The pointer years are quantified in standard deviation

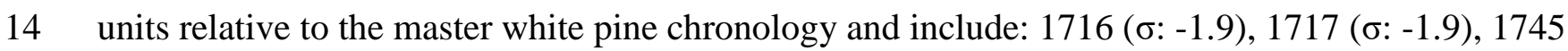

15 ( $\sigma:-2.6), 1750(\sigma: 2.3), 1771(\sigma:-2.3), 1792(\sigma:-2.1), 1839(\sigma:-1.9)$, and $1840(\sigma:-1.9)$. Regional

16 coherencies are also visually evident in comparing the Ottawa River-Petawawa and Ottawa-

17 Gatineau chronologies, such as the sharp growth decline centered around 1840 (Fig. 3d). Overall,

18 the results show that the Ottawa River-Petawawa and Ottawa-Gatineau heritage ring-width series

19 are regionally coherent and properly aligned. We now turn our attention to the individual heritage

20 site chronologies, their tree-ring-inferred age assignments, and how these results compare to other

21 sources of information compiled by the NCC and used to approximate the construction date of the

22 buildings. 


\section{Anderson Barn}

The Anderson Barn (Fig. 4) is part of a farmstead located in the National Capital Greenbelt, a rural area surrounding the urban core of Ottawa (Fig. 1). There are four main structures on the farmstead including a red-brick house (ca. 1930s), a large metal shed (ca. 1970s), and two barns thought to be of ca. 1860 vintage based on architectural similarities to a nearby barn of known age (Contentworks Inc., 2006). The focus of this study is the smaller of the two barns, as the larger barn could not be safely sampled. Anderson Barn is named after Joseph Anderson and family who had farmed this property for much of the late $20^{\text {th }}$ century until 2005 . Based on land registry documents from NCC archives, the first occupants of the property were David Mackey and John White in AD 1879 (Contentworks Inc., 2006). However, this earliest occupation date is roughly two decades younger than the ca. 1860 estimate.

Cores were taken from five wall logs of the barn. The waney edge was visibly intact and accessible along the gap between wall logs (Fig. 4). The Anderson Barn mean chronology is well matched with the regional pine chronology if the terminal ring is assigned to AD 1865 . Over the period that the Anderson Barn chronology is defined by 2 or more logs (AD 1712-1864), it is well correlated with the master white pine chronology $(\mathrm{r}=0.55, \mathrm{t}=8.1, \mathrm{p} \leq 0.01)$ with $68 \%$ agreement for the sign-test $(\mathrm{p} \leq 0.01)$. Visual comparison of the chronologies reveals strong regional coherence (Fig. 5a). The terminal ring of each of the five logs sampled was dated to AD 1865 and contained late-wood cells, meaning that all logs were felled during or after the late summer of 1865 , but before the 1866 growing season had begun. It is unknown if the logs were used immediately after harvest, but if they were it would follow that the barn was built around late 1865 or early 1866. The tree-ring inferred construction timeline pre-dates the first known occupation of the property (ca. 1879) by more than a decade, but generally supports the approximated age of the 
1 barn (ca. 1860) based on its architectural similarity to a nearby barn of known age (Contentworks

2 Inc., 2006). The tree-ring inferred construction date provides important context for evaluating this

3 structure's heritage value, but leaves unanswered the question of who occupied this property

4 before it was first registered. This, however, is beyond the scope of our study.

5

\section{Rideau Hall Visitor's Centre}

7

The Rideau Hall Visitor's Centre (Fig. 4) is one of several buildings on the grounds of the Rideau Hall Estate at 1 Sussex Drive in Ottawa (Fig. 1). Rideau Hall is a national historic site and the official residence of the Governor General of Canada. The oldest wing of the Visitor's Centre first served as a guard house, and later as the residence of the caretaker and gardener of the Rideau Hall Estate. A report prepared by the Federal Heritage Buildings Review Office provides a summary of historical records for the Visitor's Centre, indicating that a pre-1838 construction date is most likely (Miquelon, 2007). However, the exact construction date is unknown. Originally, the building was a single story dwelling, but renovations and additions in 1867, 1893, 1912 and 1996 have modified its appearance and functionality. It is now used as an interpretation centre, gift shop, and rest area for visitors to the Rideau Hall Estate.

Cores were collected from log beams inside a crawlspace beneath the north section of the building (Fig. 4), which dates to the original construction. Only three log beams were sampled. No other beams were suitable either because they were from recent renovations or were compromised by rot. Two of the sampled beams were squared on all sides, but with some portion of the waney edge intact. The third beam was also squared and the waney edge was present in some areas, but it was partially deteriorated suggesting that some of the final growth rings may have been lost. The Rideau Hall Visitor's Centre chronology matches the regional pine chronology when its terminal 
1 ring is assigned to $\mathrm{AD} 1830$. Despite the fact it is defined by few independent samples $(\mathrm{n}=3)$, the

2 site chronology is strongly correlated with the master white pine chronology over the period

3 defined by at least $2 \operatorname{logs}(1736-1829 ; \mathrm{r}=0.71, \mathrm{t}=9.6, \mathrm{p} \leq 0.01)$, and with $81 \%$ agreement for the

4 sign-test $(\mathrm{p} \leq 0.01)$. This coherence is also evident from a visual comparison of the two

5 chronologies (Fig. 5b). The terminal rings of the two logs with intact waney edges dated to AD

6 1830, while the partially deteriorated log had a terminal ring date of AD 1822. The two logs dating

7 to $\mathrm{AD} 1830$ both had latewood, meaning they were felled during or after the late summer of AD

81830 , but before the AD 1831 growing season had begun. Again, it is unknown if the logs were

9 used immediately after they were felled, but if they were the original structure can be dated to late

101830 or early 1831, in agreement with the NCC report suggesting a pre-AD 1838 construction.

11

12

\section{Cherry Cottage}

The Cherry Cottage (Fig. 4) is in Gatineau, Quebec (Fig. 1). Two information plaques are mounted on the side of the Cherry Cottage. A Centennial plaque issued by the City of Gatineau (formerly Aylmer) in 1967 states that the Cherry Cottage was built by Charles Carey Symmes in the ca. AD 1840s. The second plaque is the 1992 Annual Heritage Prize awarded by the Aylmer Heritage Association and the Government of Quebec's Ministry of Cultural Affairs, and indicates a more precise construction date of AD 1837. In addition to these disparate construction dates, Aldred (1989) recounts Symmes' arrival in AD 1840 and early business ventures, but states that he moved into his "newly built" house (i.e., the Cherry Cottage) in AD 1852.

Five log beams were cored in the basement of the Cherry Cottage (Fig. 4), each with its waney edge intact. The Cherry Cottage chronology is best correlated with the master white pine chronology when its terminal ring is assigned to AD 1850. Over the period the Cherry Cottage and 
1 master white pine chronologies are defined by 2 or more logs (AD 1695-1849), a correlation of

$20.39(\mathrm{t}=5.2, \mathrm{p} \leq 0.01)$ is observed (Fig. 5c). This correlation is considerably weaker than the

3 correlations between the master white pine chronology versus the Anderson Barn or Rideau Hall

4 Visitor's Centre chronologies. This lower correlation may reflect local environmental factors that

5 may have dampened the regional climate signal in the Cherry Cottage tree-rings. Regardless, the

6 correlation is significant and demonstrates some degree of shared regional variability, and the sign-

7 test result of $68 \%$ agreement $(\mathrm{p} \leq 0.01)$ supports the age assignment of the Cherry Cottage

8 samples. The terminal rings of the Cherry Cottage logs did not contain late-wood and, thus, were

9 felled some point during the AD 1850 growing season. A construction date of ca. 1850 agrees well

10 with Aldred's (1989) historical account of Symmes and family moving into the newly built house

11 in AD 1852, but does not support the construction dates of AD 1837 and ca. AD 1840s indicated

12 on the information plaques. In spite of this slightly younger construction date, the Cherry Cottage

13 is an important heritage asset and is representative of houses built by prominent entrepreneurs and

14 businessmen drawn to the region in the mid- $19^{\text {th }}$ century by the booming lumber industry.

Brigham-Chamberlin Barn The Brigham-Chamberlin Barn (Fig. 4) is on the fringe of the Gatineau Park near Chelsea,

18 Quebec (Fig. 1). A report prepared by the Federal Heritage Buildings Review Office explains that

19 the barn is associated with two pioneer families, the Brighams and the Chamberlins, who settled in

20 the area and became united through marriage in ca. AD 1850, and the barn itself is thought to date

21 to the time of their union (Clerk, 2002). This date of origin is also noted on an NCC information

22 panel mounted on the barn. The assumed vintage of the barn makes it of obvious heritage

23 importance to the NCC. It has been identified as a cultural resource for which a conservation plan 
1 will be developed and there is interest from the Park to integrate the barn into their educational 2 program (NCC, 2013).

Five logs with intact waney edges were sampled (Fig. 4). The Brigham-Chamberlin Barn

4 chronology is best matched with the regional pine chronology when the terminal ring is assigned to

5 AD 1862. Over the period defined by 2 or more logs (AD 1736-1861), the correlation between the

6 Brigham-Chamberlin chronology and master white pine chronology was relatively strong $(\mathrm{r}=$

$70.68, \mathrm{t}=10.3, \mathrm{p} \leq 0.01)$ with $76 \%$ agreement $(\mathrm{p} \leq 0.01)$ for the sign-test. A visual comparison of

8 the chronologies shows strong regional coherence and proper age alignment of the Brigham-

9 Chamberlin samples (Fig. 5d). There is some range in felling dates for the five logs. Three of the

10 logs had terminal rings dating to $\mathrm{AD} 1862$, one dating to $\mathrm{AD} 1861$, and the fifth dating to $\mathrm{AD}$

11 1859. The samples dating to AD 1862 had late-wood, suggesting these logs were felled during or

12 after the late summer of 1862 , but before the 1863 growing season had begun. The range of felling

13 dates might be interpreted as evidence that the Brigham-Chamberlin Family started to harvest the

14 logs several years before the barn was built or that it was completed in stages, but most certain is

15 that it was not finished before late 1862. Assuming the barn was completed around AD 1862, the

16 ca. AD 1850 estimate assumed from the Brigham-Chamberlin marriage appears to be more than a

17 decade too old.

18

Healey Lodge

The Healey Lodge (Fig. 4) is typical of farmsteads established by British, Irish, American and French Canadian pioneers in the Gatineau Hills in the 1800s. It is located deep in the Gatineau

22 Park near Harrington Lake (Fig. 1). Recent rehabilitation work has converted this former dwelling

23 into an all-season rest stop for outdoor enthusiasts. There are several contradicting accounts 
1 regarding the date of construction of the house. An information panel at the site, produced by the

2 NCC, indicates that in AD 1863, Irish immigrants Edward and Bridget Healey established a 200-

3 acre homestead (i.e., the Healey Lodge) where they farmed potato crops and livestock. Another,

4 earlier analysis by Latté (1975) identifies a construction date of ca. 1850. Lastly, an oral history

5 account by descendants of Edward and Bridget Healey suggests that this property was settled in

6 the 1830s or 1840s (NCC, 1981).

$7 \quad$ Nine wall logs were sampled at the Healey Lodge, seven with intact waney edges (Fig. 4).

8 The Healey Lodge chronology is best matched with the master white pine chronology when the

9 terminal ring is assigned to AD 1853. Over the period defined by 2 or more samples (AD 1710-

10 1852) the Healey Lodge chronology and master white pine chronology are strongly correlated $(\mathrm{r}=$

$110.73, \mathrm{t}=12.6, \mathrm{p} \leq 0.01)$ with a sign-test result of $82 \%$ agreement $(\mathrm{p} \leq 0.01)$. The strong coherence

12 between the chronologies is also visually evident (Fig. 5e) and supports the age assignment. All

13 seven logs with intact waney edges had terminal ring dates of AD 1853, and each with late-wood

14 indicating that they were felled during or after the late summer of $\mathrm{AD} 1853$, but before the $\mathrm{AD}$

151854 growing season began. The other two logs with slightly damaged waney edges had terminal

16 ring dating to $\mathrm{AD} 1851$ and 1852 . If the logs were used soon after they were felled, an approximate

17 construction date of AD 1853 can be assigned to the Healey Lodge. This finding agrees with the

18 date of construction suggested by Latté (1975), but does not support the dates of AD 1863 or AD

191830 s to 1840 s based on other historical accounts. The tree-ring results help to resolve the debate

20 about this structure's age, and provide important context for evaluating its heritage value.

21

22 Herridge Lodge 
The Herridge Lodge (Fig. 4) is located in close proximity to the Healey Lodge (Fig. 1), and

2 has undergone a similar conversion to a rest stop for Park visitors. According to historical records

3 compiled by the NCC, summarised on an information panel at the site, Herridge Lodge was

4 originally the homestead of Irish settlers by the name of Cafferty, and was later purchased by

5 lawyer William Duncan Herridge (Clerk, 2006). The historical records for this site are not as

6 detailed as those for the Healey Lodge, however the structure stands as a good example of the

7 country retreats in the Gatineau Hills sought by wealthy politicians, industrialists and civil servants

8 from Ottawa in the late 1800s. The Federal Heritage Building Review Office has estimated that

9 Herridge Lodge was built around ca. AD 1880 (Clerk, 2006), which coincides with a time of

10 bustling development and land acquisitions in the Park from ca. AD 1850 onwards.

11 Seven wall logs were sampled at the Herridge Lodge, six with pristine waney edges. The

12 Herridge Lodge chronology matches the master white pine chronology when its terminal ring is set

13 to AD 1878. Over the period defined by 2 or more logs (AD 1734-1877), the two chronologies are

14 strongly correlated $(\mathrm{r}=0.72, \mathrm{t}=12.3, \mathrm{p} \leq 0.01)$ with a sign-test result of $74 \%$ agreement $(\mathrm{p} \leq$

15 0.01). A visual comparison further demonstrates that the Herridge Lodge chronology is properly

16 aligned (Fig. 5f). Of the six logs with intact waney edges, four had terminal rings that dated to AD

171878 and two had terminal rings dating to AD 1877. The seventh log had a damaged waney edge

18 with a terminal ring dating to AD 1875. All of the rings assigned to AD 1878 contained late-wood

19 and, thus, were felled during or after the late summer AD 1878, but before the AD 1879 growing

20 season had begun. If the logs were used soon after harvest, Herridge Lodge was likely built in AD

211878 or 1879 , in close agreement with the approximation made by the NCC based on Park

22 documents and the settlement history of the area. 


\section{CONCLUSION}

2 Nineteenth century heritage structures represent an important era in the development of the

3 National Capital Region, comprising the growth of the lumber industry, the establishment of rural

4 farmsteads in the areas now comprising Gatineau Park and agricultural lands surrounding Ottawa,

5 and construction of the Rideau Hall Estate which remains a heritage property central to Canadian

6 government. Historical records are often associated with the properties of heritage structures, and

7 play an important role in reconstructing settlement histories, but finer details about these structures

8 including construction dates are often uncertain and cannot be approximated with much accuracy

9 from historical records, especially for modest vernacular structures. Tree-ring growth patterns of

10 logs used to build the structures, on the other hand, provide a physical record of tree harvest and a

11 likely construction timeline. This study demonstrated the viability of dendroarchaeology methods

12 in Canada's National Capital Region for dating $19^{\text {th }}$ century heritage log structures built from local

13 eastern white pine timbers. The master white pine chronology developed here could potentially be

14 used to date other important heritage structures and artefacts in eastern Canada as well, including

15 aboriginal dugout canoes (Johnston, 1962; Rogers, 1965; Mitchell, 1968) or British naval ships

16 from the Napoleonic Wars, which relied heavily on Ottawa Valley timbers (Legget, 1975). Finally,

17 it is notable that the coherence of white pine growth patterns in the study region implies a regional

18 growth signal that may be related to broad-scale climate patterns. Therefore, the regional

19 chronology developed here may yield insights on the region's climate history beyond the relatively

20 short instrumental record.

21

\section{ACKNOWLEDGEMENTS}


1 We thank Logs End for cross-sections of the Ottawa River logs, R. Wilson and H. Grissino-Mayer

2 for their suggestions on dry-wood borer design, D. Maitland for access to the Gatineau Park

3 buildings, and M. Dixon and N. Huard for allowing us to include Cherry Cottage in the study.

4 Finally, we thank two anonymous reviewers and Associate Editor Q.-B. Zhang for their valuable

5 comments which improved this paper. Financial support for this research was provided through an

6 NSERC Discovery Grant to M.F.J. Pisaric.

7

\section{REFERENCES}

9 Aldred, D., 1989. Alymer Québec: Its Heritage, Son Patrimoine. Aylmer Heritage Association, Aylmer, 228 pp.

Becker, B., Billamboz, A., Egger, H., Gassmann, P., Orcel, A., Orcel, C., Ruoff, U., 1985. von Pfahlbausiedlungen nördlich der Alpen im Jahrringkalender Mitteleuropas. Antiqua $11,1-68$.

Canadian Forest Service, 1998. The State of Canada's Forests 1997-1998: The people's forests. Natural Resources Canada, Headquarters, Policy, Planning and International Affairs Branch, Ottawa, 108 pp.

Clerk, N., 2006. Report 06-111: Chalet Herridge. Federal Heritage Buildings Review Office, Parks Canada, Gatineau, 24 pp.

22 Contentworks Inc., 2006. NCC Farmstead Identification 331 Record Heritage Value Assessment. Evolution of Farming in the National Capital Greenbelt - Part 2 - Farmsteads. Ottawa, 2 
pp.

2 Getty, H.T., 1935. New dates from Mesa Verde. Tree-Ring Bulletin 1(3): 21-23.

3 Grissino-Mayer, H. D.,1993. An updated list of species used in tree-ring research. Tree-Ring

4 Bulletin 53, 17-43.

5 Grissino-Mayer, H.D, Sheppard, P.R., Cleavland, M.K., 2004. A dendroarchaeological reexamination of the "Messiah" violin and other instruments attributed to Antonio Stradivari. Journal of Archaeological Science 31, 167-74.

Grissino-Mayer, H.D., Kobziar, L. N., Harley, G. L., Russell, K. P., LaForest, L. B., Oppermann, J. K., 2010. The Historical Dendroarchaeology of the Ximénez-Fatio House, St. Augustine,

Guyette, R.P., and Cole, W.G., 1999. Age characteristics of coarse woody debris (Pinus strobus) in Florida, U.S.A. Tree-Ring Research 66: 61-73.

Guyette, R.P., and Dey, D.C., 1995. Age, size, and regeneration of old growth white pine at Dividing Lake Nature Reserve, Algonquin Park, Ontario. Forest Research Report No. 131, Ontario Ministry of Natural Resources, Sault Ste. Marie, 1-11.

Holmes, R.L., 1983. Computer-assisted quality control in tree-ring dating and measurement. TreeRing Bulletin, 43, 69-78.

Johnston, R.B., 1962. Another dugout canoe from Ontario. American Antiquity 28, 95-96.

Latté, R., 1975. Report H14-565: The Healey Log House. Ottawa, 1 pp.

Legget, R.F., 1975. Ottawa Waterway: Gateway to a Continent. University of Toronto Press, 291

21 pp.

Miquelon, N., 2007. Report 07-397: Rideau Hall Visitor Centre. Federal Heritage Buildings Review Office, Parks Canada, Gatineau, 33 pp. 
1 Mitchell, B., Croft, D.A., McQuade, J.H., 1968. A dugout canoe from Renfrew County, Ontario. $2 \quad$ American Antiquity 33, 501-02.

3 NCC, 1981. Dossier H14-565 LH: Compte rendu de 1'entrevue avec Stan (Steven Arthur) Healey. $4 \quad$ Ottawa, 1 pp.

5 NCC, 2013. Public Consultation Report: Gatineau Park Cultural Heritage Plan. Ottawa, 11 pp.

6 Pearson, C.L., Griggs, C.B., Kuniholm, P.I., Brewer, P.W., Ważny, T., Canady, L., 2012,

7 Dendroarchaeology of the mid-first millennium AD in Constantinople. Journal of Archaeological Sciences 39, 3402-14.

9 Pickard. F., Robichaud, A., Laroque, C., 2011. Using dendrochronology to date the Val Comeau canoe, New Brunswick and developing an eastern white pine chronology in the Canadian Maritimes. Dendrochronologia 26, 3-8.

Robichaud, A., and Laroque, C., 2008. Dendroarchaeology in southwestern Nova Scotia and the construction of a regional red spruce chronology. Tree-Ring Research 64(1), 17-25.

Rogers, E.S., 1965. The dugout canoe in Ontario. American Antiquity 30, 454-59.

Selig, N., Laroque, C., Marsh, S., 2007. Dendroarchaeological investigations in the Maritimes: a case study of Dorchester House, New Brunswick. Material Culture Review 66, 42-49.

Smith, D. J., 2000. Dendrochronological investigations of historic cabins in Jasper and Banff National Parks. Prepared for Parks Canada, Western Region. University of Victoria TreeRing Laboratory Report 2000-4.

Smith, D. J., Mackie, A. P., Sumpter, I. D., 2005. Building Quaksweaqwul: Dendroarchaeological investigations at Kiix?in National Historic Site, Vancouver Island, Canada. Dendrochronologia 22, 195-201.

23 Speer, J.H., 2010. Fundamentals of Tree-Ring Research. University of Arizona Press, Tucson, 252 
pp.

2 Wang, S.-Z., Shaob, X., Xuc, X., Xiaoc Y., 2008, Dating of tombs in Delingha, Qinghai Province, 3 China, on the basis of a 2332-year tree-ring juniper chronology (Sabina przewalskii Kom)

4 (1575 BC-756 AD). Dendrochronologia 26, 35-41.

5

6

7

8

9

10

11

12

13

14

15

16

17

18

19

20

21

22

23 


\section{$1 \quad$ Figure captions}

2 Figure 1. Regional-scale map of the Ottawa River watershed ('PRF' is the Petawawa Research

3 Forest), and local-scale map (lower-left) of the six study sites in the Ottawa-Gatineau area.

Figure 2. End cut from an eastern white pine log recovered from the bed of the Ottawa River. This sample is marked with the stamp of John R. Booth (bottom right), one of Ottawa's most successful lumber barons of the $19^{\text {th }}$ century. The typical ring structure of this species (upper right) consists of sharp ring boundaries, rays, a narrow latewood band, and a gradual earlywood-latewood transition containing resin ducts.

Figure 3. (a) Temporal coverage of the Ottawa River (grey bars) and Petawawa Research Forest Petawawa mean chronology (black); all individual Ottawa River and Petawawa ring-width indices are shown in light grey. (c) Temporal coverage of Ottawa-Gatineau archaeological samples (grey bars). (d) Comparison of the Ottawa-Gatineau mean chronology (dark grey) and a composite Ottawa River-Petawawa mean chronology (black); all individual Ottawa-Gatineau ring-width indices are in light grey. Correlation and sign-test results are for periods for which the series being compared are defined by $\geq 2$ trees; all statistical results are significant at $p \leq 0.01$.

Figure 4. Study sites and examples of sampled logs.

Figure 5. Comparisons between the regional chronology (black) and mean site chronologies (dark grey) for: (a) Anderson Barn; (b) Rideau Hall Visitor's Centre; (c) Cherry Cottage; (d) BrighamChamberlin Barn; (e) Healey Lodge; and (f) Herridge Lodge. The final growth ring for each site chronology was not plotted because the completeness of the final ring cannot be known. For each comparison, the regional white pine chronology was re-calculated by excluding series from the site of interest, so that correlations were independent. Temporal coverage of individual series for each site chronology is indicated (grey bars). Correlation and sign-test results are reported for periods that both comparison series are defined by $\geq 2$ trees; all results are significant at $p \leq 0.01$. 


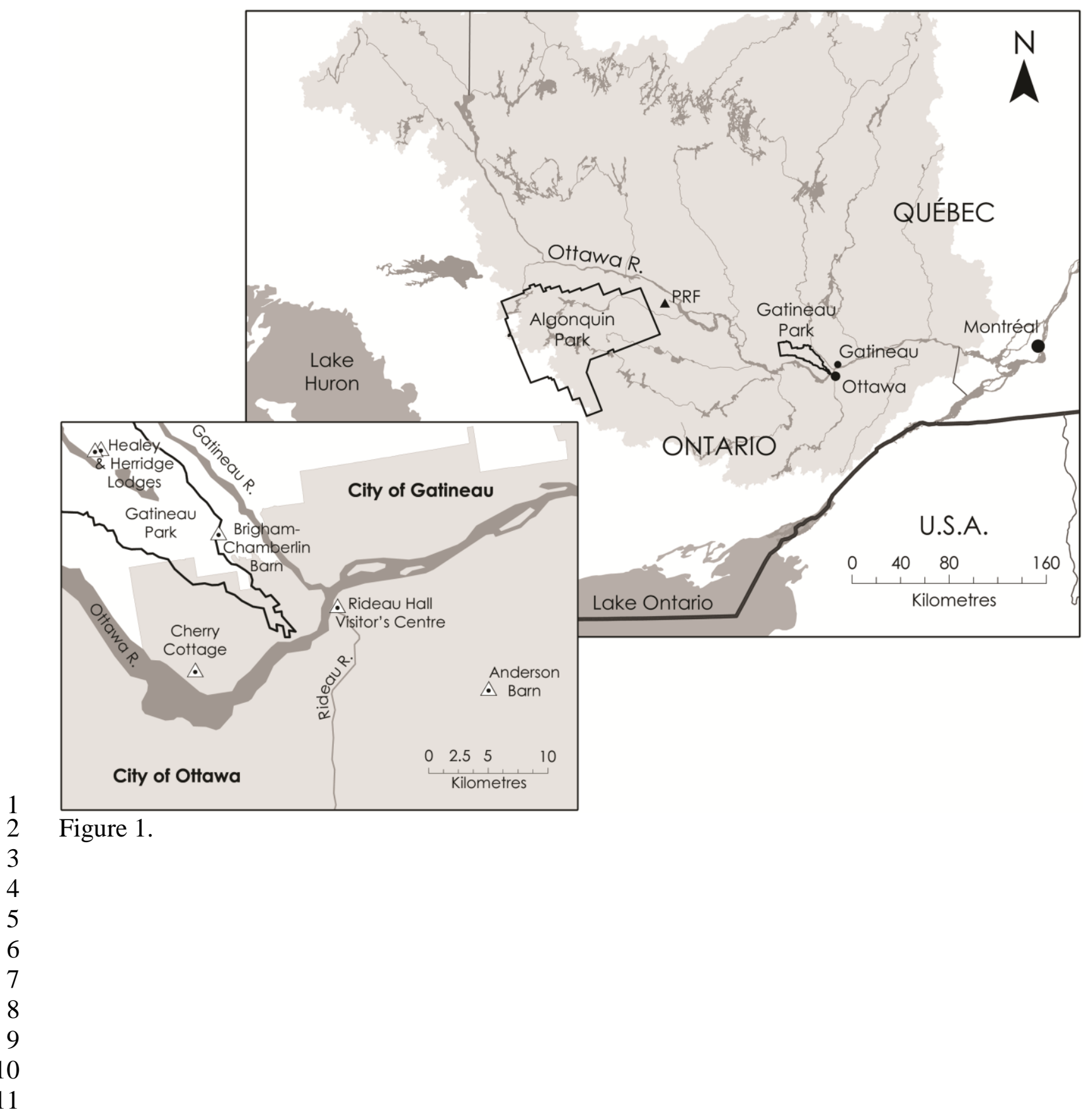




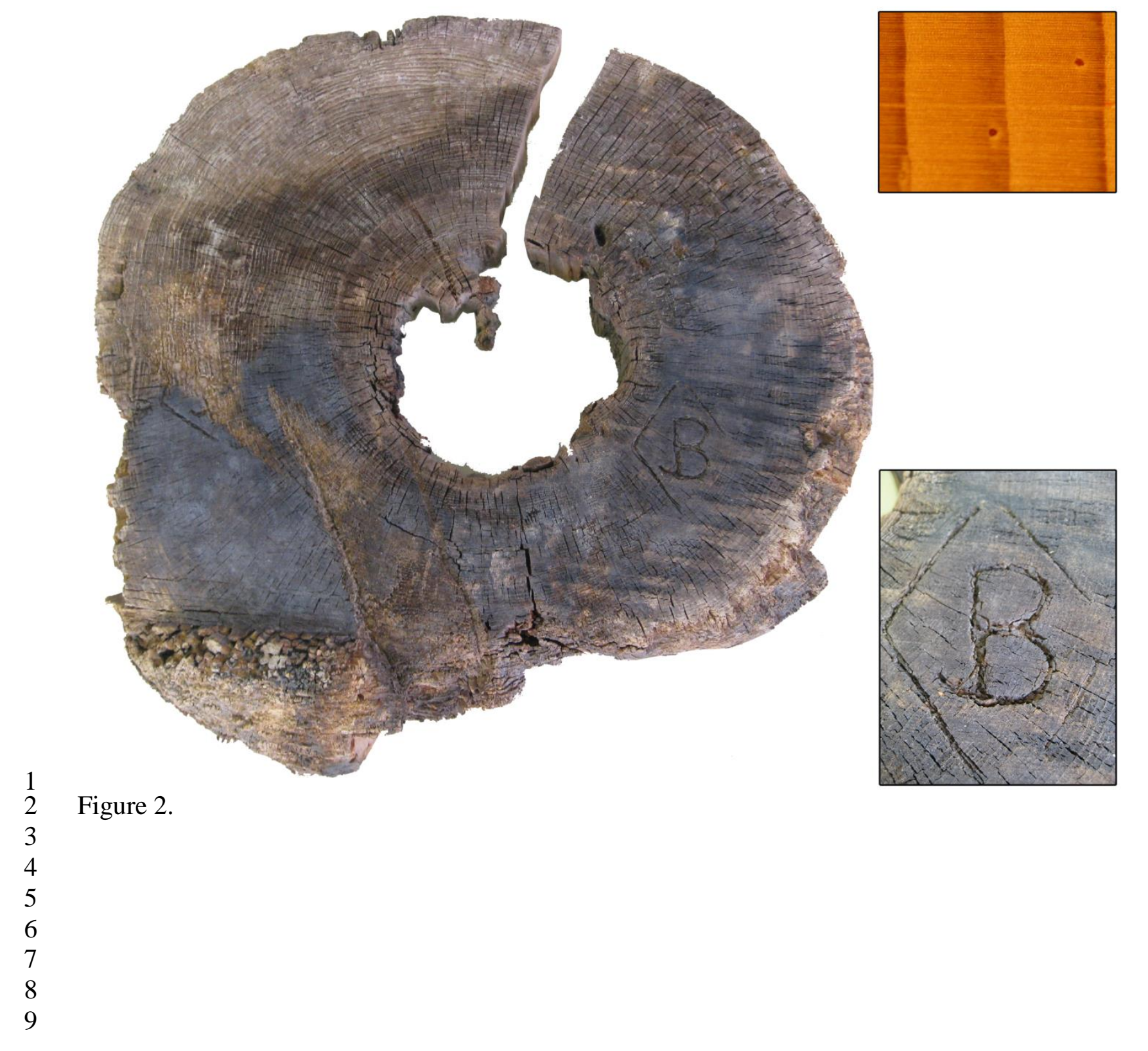




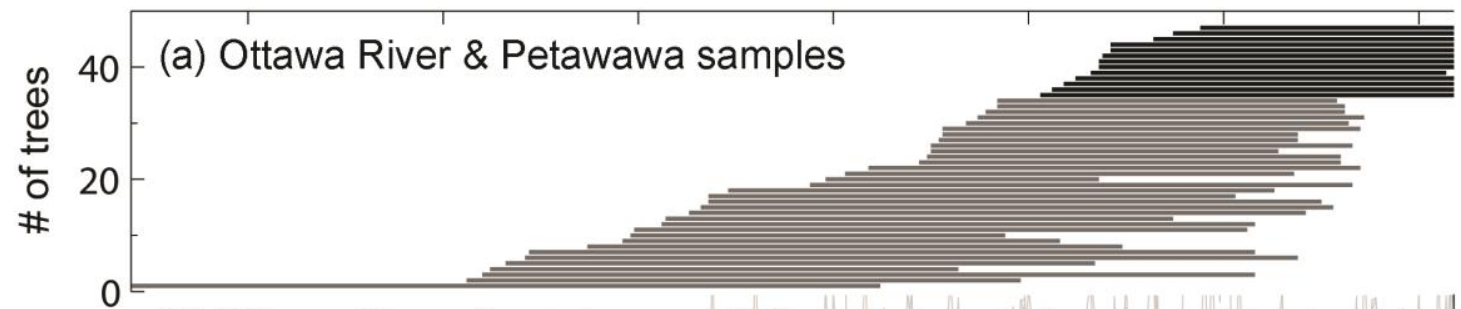

(b) Ottawa River chronology vs. Petawawa chronology
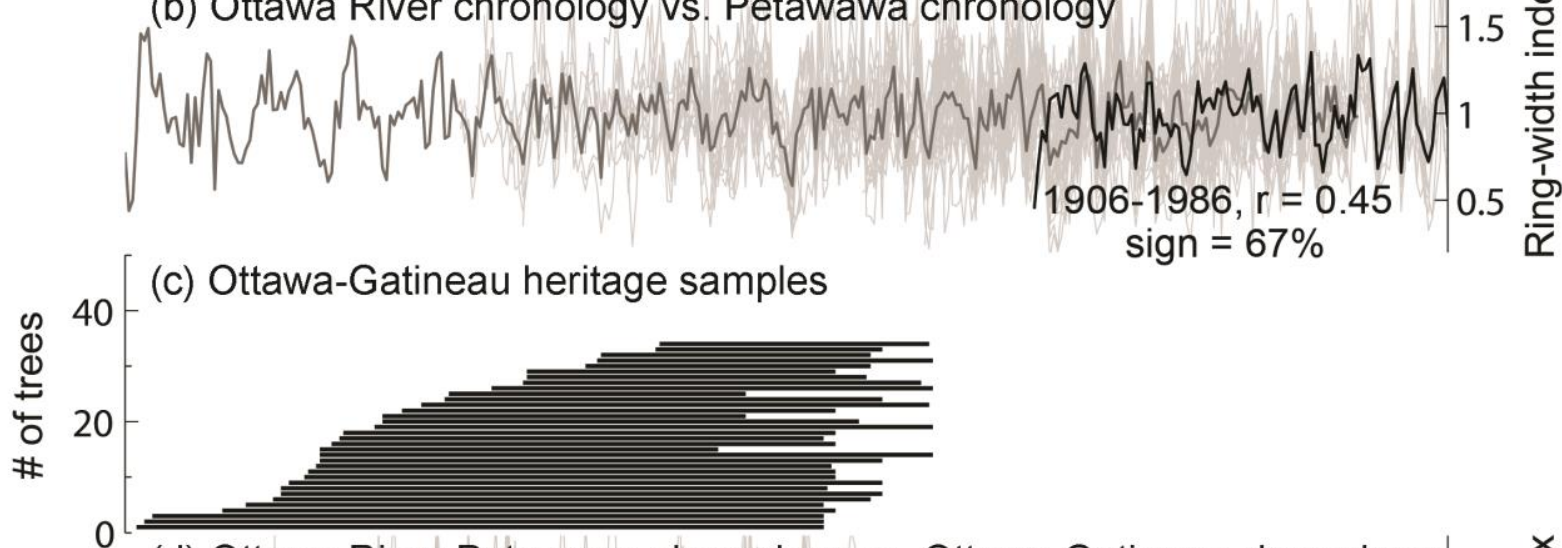

(d) Ottawa River-Petawawa chronology vs. Ottawa-Gatineau chronology $\left.\right|_{-1.5} \stackrel{x}{\stackrel{x}{c}}$

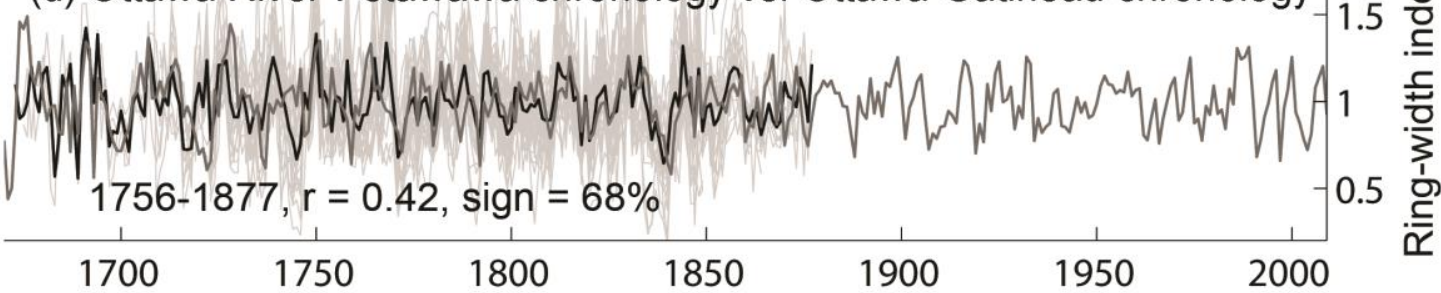
Year A.D.

Figure 3. 


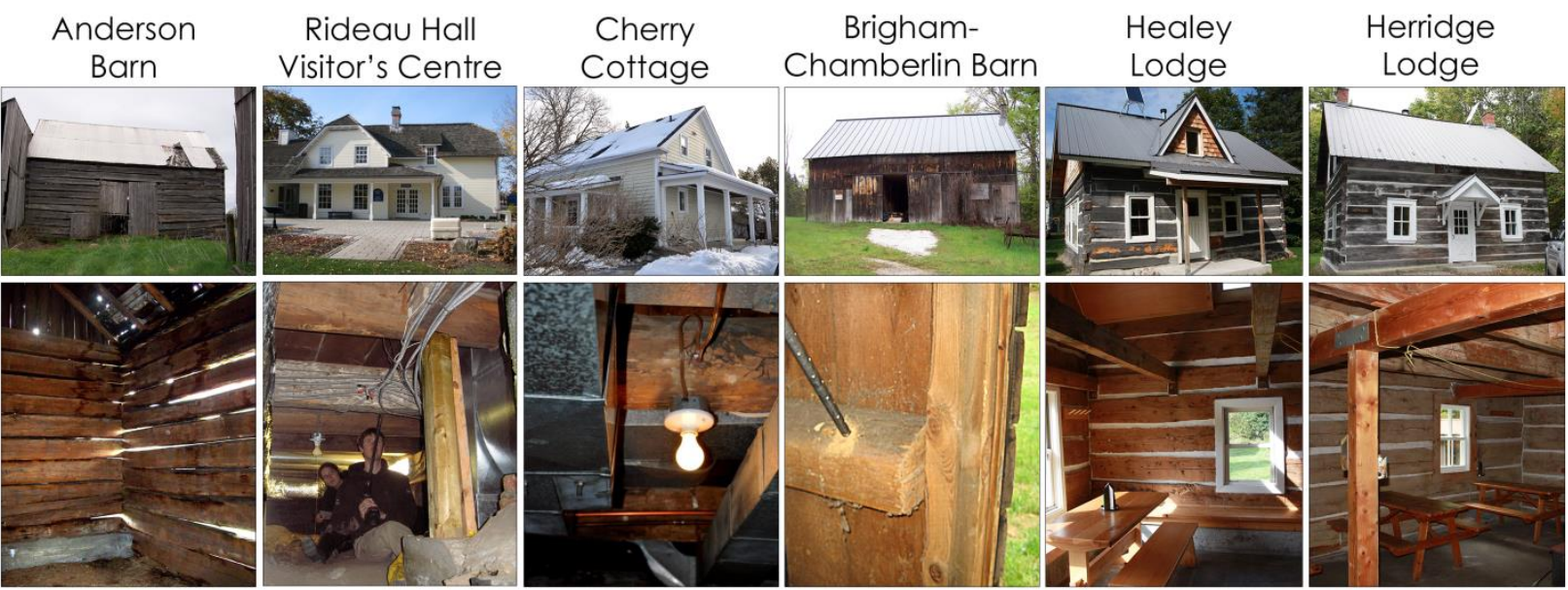

Figure 4.

3

4

5

6

7

8

9

10

11

12

13

14

15

16

17

18

19

20

21

22

23 

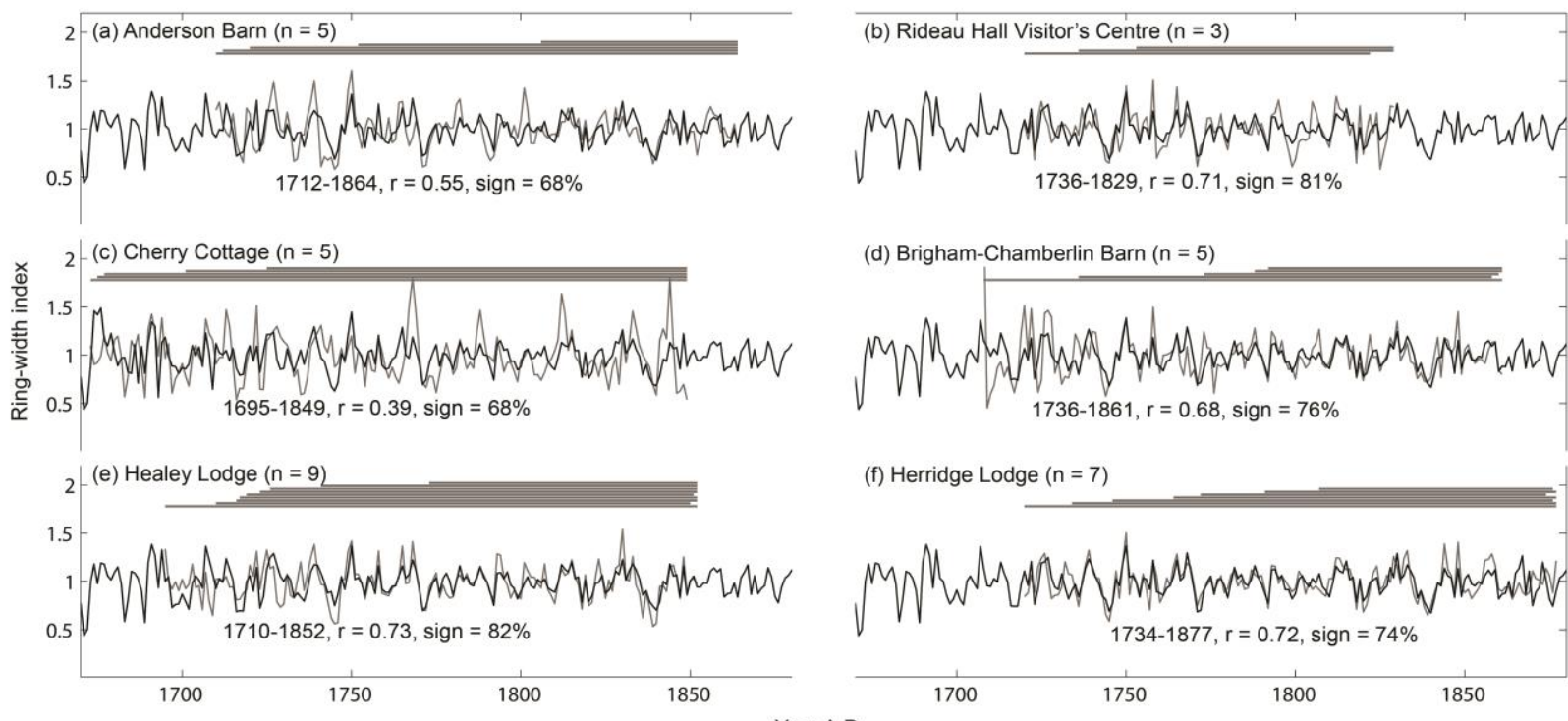

1 Figure 5. 